\title{
Dural amyloidoma
}

\section{An unusual presentation of CNS amyloidosis}

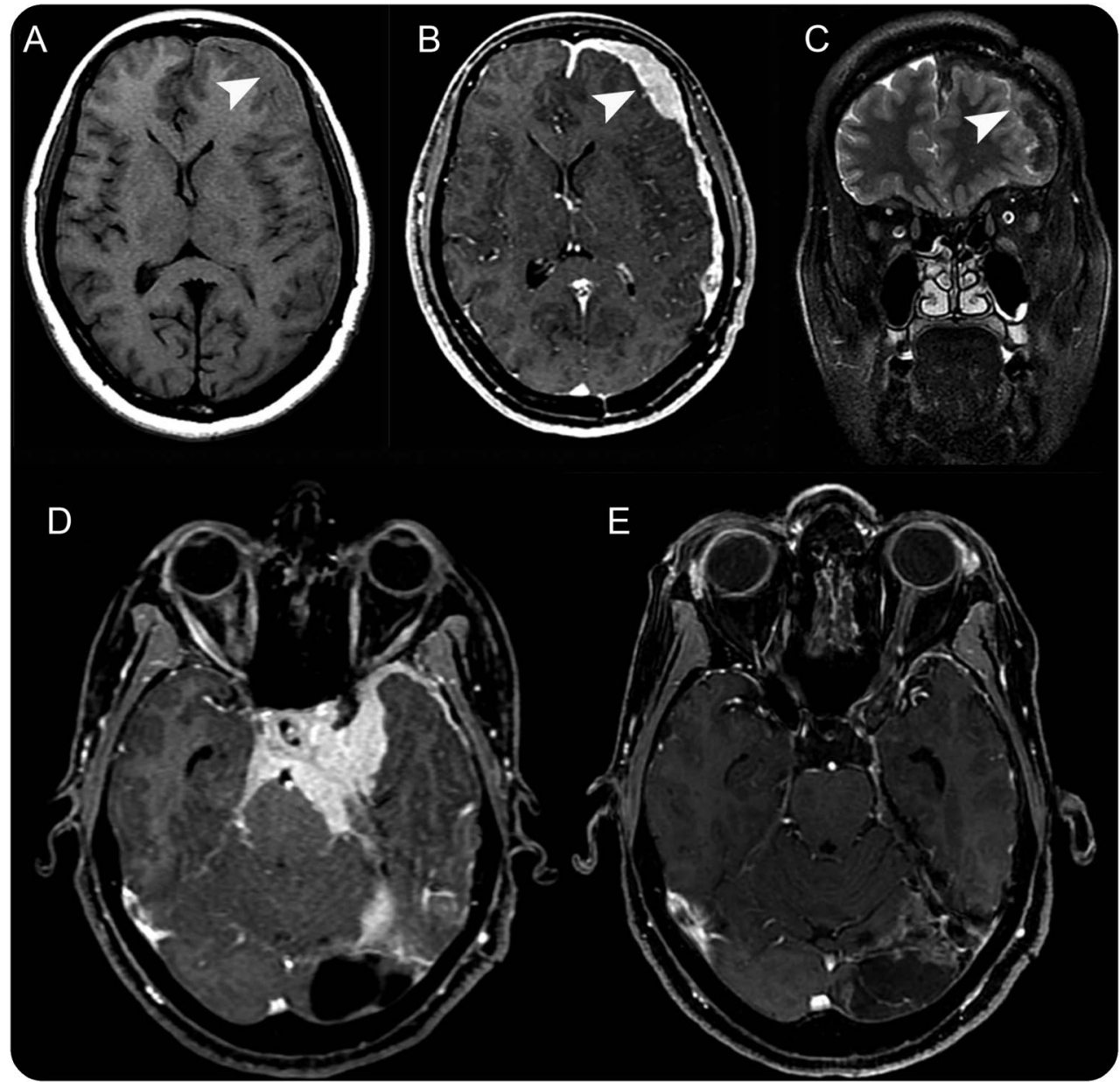

MRI scans exhibit an extensive dural thickening over the cerebral falx and left frontoparietal convexity (arrowheads), which is characterized by intermediate signal intensity on axial T1-weighted images (A) with intense enhancement following IV gadolinium administration (B). (C) The coronal T2-weighted image shows the lesion has predominantly low signal intensity. (D) Three-year follow-up MRI shows lesion progression characterized by dural enhancement in the cavernous sinuses and posterior and temporal fossa on the left side. (E) Six-year follow-up MRI shows significant resolution of contrast enhancement. The patient was treated with corticosteroids and brain irradiation.

A 46-year-old previously healthy woman presented with recurring left frontal and occipital headache. A brain MRI demonstrated diffuse dural thickening (figure 1, top). CSF analysis showed no abnormalities. A meningeal biopsy had pathology typical of an amyloid tumor (figure 2). Further investigations did not reveal evidence of plasma-cell tumor, multiple myeloma, systemic amyloidosis, underlying inflammatory disorder, or malignancy. Follow-up brain MRIs revealed regression of the pachymeningeal disease after treatment with corticosteroids and radiotherapy (figure 1, bottom).

Amyloidosis is a group of diseases characterized by the extracellular deposition of amyloid protein. ${ }^{1}$ Extraaxial locations are rare, ${ }^{2}$ but dural amyloidoma should be considered in the differential diagnosis of diffuse meningeal thickening despite the absence of systemic amyloidosis. 


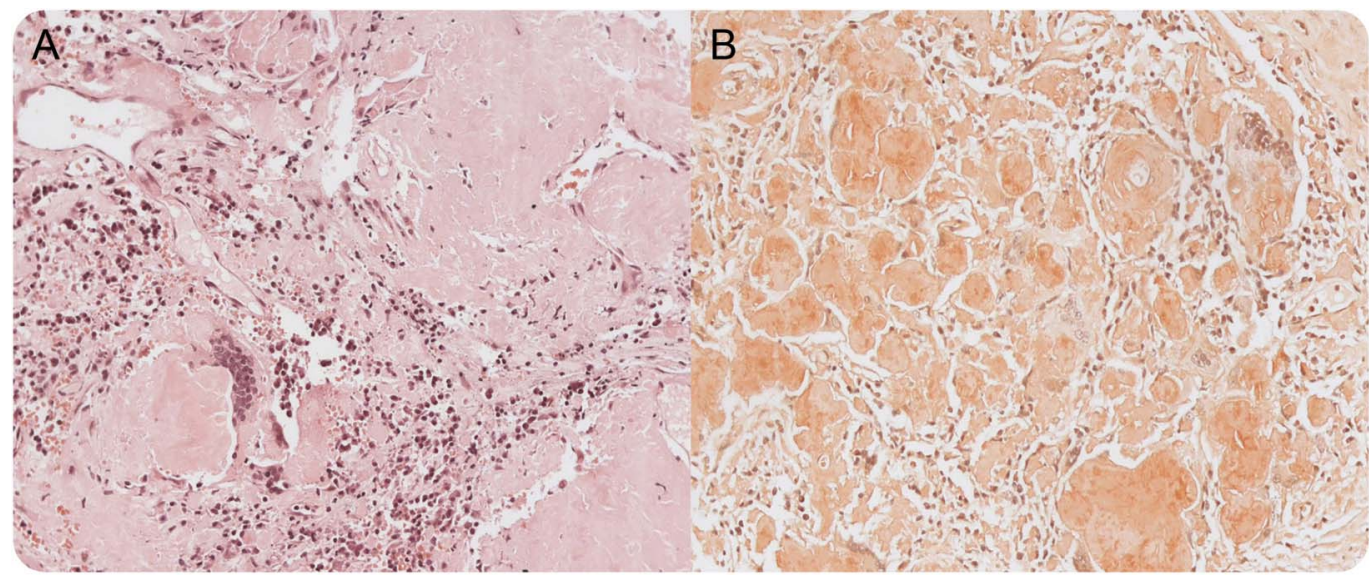

(A) Hematoxylin \& eosin and (B) Congo red-stained biopsy sections exhibit fibroconjunctive tissue infiltrated by multinucleated giant cells and lymphomononuclear cells surrounding amorphous deposits of eosinophilic material (original magnification $\times 50$ ).

Simone Shibao, MD, PhD, Fabio A.R. Dalprá, MD, Celi S. Andrade, MD, PhD, Claudia C. Leite, MD, PhD From the Faculdade de Medicina da Universidade de São Paulo, Brazil.

Author contributions: Dr. Shibao: study concept, revision of the manuscript. Dr. Dalprá: clinical and radiologic data, patient consent, revision of the manuscript. Dr. Andrade: study design, drafting and revision of the manuscript. Dr. Leite: revision of the manuscript, study supervision.

Study funding: No targeted funding reported.

Disclosure: S. Shibao and F. Dalprá report no disclosures relevant to the manuscript. C. Andrade is a recipient of a postdoctoral grant from FAPESP (São Paulo Research Foundation, grant 2012/00398-1). C. Leite is supported by CNPq (National Council for Scientific and Technological Development, grant 308267/008-7). Go to Neurology.org for full disclosures.

Correspondence to Dr. Andrade: celi.andrade@usp.br

1. Tabatabai G, Baehring J, Hochberg FH. Primary amyloidoma of the brain parenchyma. Arch Neurol 2005;62:477-480.

2. Foreid H, Barroso C, Evangelista T, Campos A, Pimentel J. Intracerebral amyloidoma: case report and review of the literature. Clin Neuropathol 2010;29:217-222.

\section{BrainPAC}

BrainPAC is the American Academy of Neurology's (AAN) federal political action committee.

- Since its inception, more than 3,000 AAN members have contributed $\$ 1,800,000$ to BrainPAC.

- BrainPAC contributed $\$ 620,000$ to candidates running for Congress in 2014.

- During the 2014 congressional campaign, 89 percent of candidates supported by BrainPAC won their elections.

BrainPAC supports both Democrats and Republicans who support issues important to the practice of neurology and the care of patients with neurologic conditions. US AAN members are invited to learn more at BrainPAC.org. 


\section{Neurology}

\section{Dural amyloidoma: An unusual presentation of CNS amyloidosis \\ Simone Shibao, Fabio A.R. Dalprá, Celi S. Andrade, et al. \\ Neurology 2016;86;1266-1267 \\ DOI 10.1212/WNL.0000000000002520}

This information is current as of March 28, 2016

\section{Updated Information \& Services}

References

Subspecialty Collections

Permissions \& Licensing

Reprints including high resolution figures, can be found at: http://n.neurology.org/content/86/13/1266.full

This article cites 2 articles, 0 of which you can access for free at: http://n.neurology.org/content/86/13/1266.full\#ref-list-1

This article, along with others on similar topics, appears in the following collection(s):

MRI

http://n.neurology.org/cgi/collection/mri

Secondary headache disorders

http://n.neurology.org/cgi/collection/secondary_headache_disorders

Information about reproducing this article in parts (figures,tables) or in its entirety can be found online at:

http://www.neurology.org/about/about_the_journal\#permissions

Information about ordering reprints can be found online:

http://n.neurology.org/subscribers/advertise

Neurology ${ }^{\circledR}$ is the official journal of the American Academy of Neurology. Published continuously since 1951 , it is now a weekly with 48 issues per year. Copyright @ 2016 American Academy of Neurology. All rights reserved. Print ISSN: 0028-3878. Online ISSN: 1526-632X.

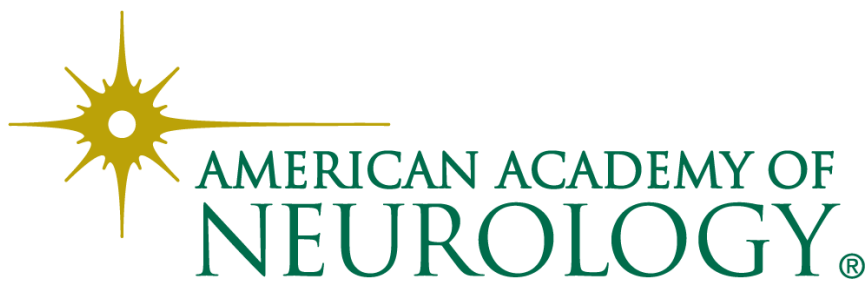

